Article

\title{
Gaining Trust in the Digital Age: The Potential of Social Media for Increasing the Competitiveness of Small and Medium Enterprises
}

\author{
Borislav Rajković $^{1, *}$, Ivan Đurić ${ }^{1}$ (D), Vlade Zarić ${ }^{2}$ and Thomas Glauben ${ }^{1}$ \\ 1 Leibniz Institute of Agricultural Development in Transition Economies (IAMO), \\ 06120 Halle (Saale), Germany; duric@iamo.de (I.Đ.); glauben@iamo.de (T.G.) \\ 2 Faculty of Agriculture, University of Belgrade, 11080 Belgrade, Serbia; vzaric@agrif.bg.ac.rs \\ * Correspondence: rajkovic@iamo.de
}

Citation: Rajković, B.; Đurić, I.; Zarić, V.; Glauben, T. Gaining Trust in the Digital Age: The Potential of Social Media for Increasing the Competitiveness of Small and Medium Enterprises. Sustainability 2021, 13, 1884. https://doi.org/ $10.3390 /$ su13041884

Academic Editor: Oliver Meixner

Received: 31 December 2020

Accepted: 2 February 2021

Published: 9 February 2021

Publisher's Note: MDPI stays neutral with regard to jurisdictional claims in published maps and institutional affiliations.

Copyright: (c) 2021 by the authors. Licensee MDPI, Basel, Switzerland. This article is an open access article distributed under the terms and conditions of the Creative Commons Attribution (CC BY) license (https:// creativecommons.org/licenses/by/ $4.0 /)$.

\begin{abstract}
Trust in information originating from a company is becoming essential, as consumer preferences are increasingly versatile and oriented towards credence attributes. Social media, which emerged as a dominant means of online communication, might help increase consumers' trust in companies. The paper empirically investigates a conceptual trust-building mechanism that could occur on companies' social media pages. A survey was conducted among social media users in Belgrade (Serbia). The collected data were analyzed using covariance-based structural equation modeling. It confirmed that in an interactive environment of companies' social media pages, trust can be built towards two objects. The first one is trust among consumers, and the second one is trust towards a company. The results also confirm a connection between trust and an intention to purchase, both being also related to a consumer's willingness to obtain information. Therefore, the result can serve as a basis for creating more effective marketing campaigns where a company is the source of information regarding credence (added-value) attributes of its products.
\end{abstract}

Keywords: consumer behavior; purchase intention; trust; social media; small and medium enterprises

\section{Introduction}

The expansion of social media with its possibilities to share consumers' opinions about products online has shifted the locus of power on markets towards the consumers [1,2]. Due to the empowerment of the demand side, requirements for information, such as origin, production processes and product flows within supply chains, are being brought to light $[3,4]$. On the other side, aspirations to build trust in their products have become easier to achieve for companies-mainly due to the rapid development of digital technologies, where transparency has become an important trust-building factor [5,6]. Lastly, there are obvious advantages of such processes for the consumers, as the information asymmetry problem can be lessened for an inexperienced consumer within such environments [7].

Interpersonal interactions provided by social media pages are identified as a fertile ground for the effects of electronic word-of-mouth (eWOM) marketing [8]. eWOM is disseminated in an online space where potential, actual or former customers can share their opinions about products [9]. By sharing their impressions or reviews, active members voluntarily generate additional value for other consumers [1]. Consumer-generated information has a bigger effect on an average consumer compared to other sources [10,11]. Members of the online networks can convince others with their knowledge and experience, helping the trust in a product and willingness to buy a product [12,13]. Grewal et al. [14] explained that the reason for such occurrence is the non-existence of incentives for WOM carriers. The explained processes also allow consumers to form opinions about the products they are not familiar with $[15,16]$. Moreover, online networking actions of individuals help 
to share values, which further helps in building trust among them [17]. Finally, eWOM also has a direct effect on the purchase intentions of consumers who are less familiar with a product $[18,19]$.

However, we also perceive the importance of trust in a company in an online environment from two different perspectives. The first one is a more tangible one: It is about a positive relation between the trust in a company and purchase intentions at the consumer level $[20,21]$. The second one is more complex; it emphasizes the role of trust when different types of information are provided by a company. We assume that the information of interest in an online environment is about a company's product(s). The products are presented with their attributes, which can be categorized as search, experience or credence attributes [22,23].

Credence attributes are increasingly becoming the point of interest among consumers, especially considering food products [24]. Companies can use such characteristics of their products as a tool to differentiate their products within the market and build competitiveness $[25,26]$. Furthermore, credence attributes represent a way of building consumer loyalty toward a brand: with higher assurance in credence attributes, consumer loyalty increases [27]. Such effects go hand in hand with a higher willingness of consumers to pay (WTP) for products having such attributes, ensuring price premiums for producers. Examples for such behavior can also be found among food industries $[28,29]$. However, the previously explained influence of eWOM in an online environment depends on the type of attributes in question. As credence attributes are the ones that cannot be checked by a regular consumer, consumers are not eligible to share their opinions about them. Moreover, consumers do not normally write online reviews about credence characteristics [30].

Today, we see a constant rise in the popularity of credence characteristics and the unsuitability of eWOM to mediate that kind of information. In our approach, we therefore mainly focus on the possibility of eWOM to increase consumers' trust in a company. Positive feedback from consumers regarding experience attributes, for example, will help to build trust in a company [19]. Once the company becomes more trustworthy, consumers' acceptance of information originating from it will be increased. The significance of this process lies in the fact that a company is an eligible source of information regarding credence characteristics of products.

The positive influence of credence attributes on consumers' purchase intentions and their WTP has already been well researched, and in the vast majority of those research works, the existence of the credence attribute in the product was non-questionable (e.g., presented as certified by a third party). However, real-world conditions gradually deter from such a setting, as companies' increasingly use social media to present a myriad of credence characteristics that surpass the range of available certificates. Thus, in conditions where homogeneous information provided with a certificate is not available, consumers' purchase intentions and WTP are largely influenced by the trust levels towards a companyan information provider. Based on those facts, we emphasize a research gap and the importance of understanding the trust-building mechanism that occurs on social media. To bridge that gap, we add to a scarce literature basis which encompasses the usage of well-grounded psychological theories in analyzing online environments and the economic behavior of an individual. Specifically, trust antecedents and trust posteriors of a consumer who interacts in an online space explain the underlying trust-building mechanism as well as its subsequent influence on purchase decisions.

We also analyze the subsequent trust influence regarding its path through the consumers' intention to obtain information in an online space. Very few papers have considered this path, and to the best of our knowledge, none of them have specified the origin of the information provided in an online space in the mentioned construct. We went a step further and regarded the origin of information in this part of the model. In our model, therefore, we were able to formulate the intention to obtain information from a company as a separate construct. We believe that this significantly increased the practical value of 
the research, as it is in line with the previously described growing role of a company as an online information provider.

We aim to answer three research questions: First, what are the main determinants of trust-building mechanisms on social media? Second, what is the influence of eWOM on the purchase intention of consumers? Lastly, how does the potential increase in the consumers' trust in a company influence their intentions to obtain company-originated information and purchase intentions?

The data were collected in Serbia, an EU candidate country where small and medium enterprises (SMEs) are facing strong competition from the EU. SMEs are of crucial importance, taking $56 \%$ of the domestic GDP and employing $66 \%$ of the workforce in the domestic economy. A total of $99 \%$ of companies there are classified as SMEs [31]. Accordingly, legislative actions propose different ways of keeping SMEs profitable, especially in the sector of food production, such as within a production of added-value products [32]. In this paper, we present a compatible approach that advances the understanding of the positive effects of social media usage on SME businesses [33].

The main contribution of this research is twofold. Firstly, it provides an in-depth understanding of trust determinants induced by social media and applicable in current market conditions by SMEs. To the best of our knowledge, this is the first study that points out the perspective of trust increase within digital solutions in this geographical region. Furthermore, we contribute to the existing discussion of the impact of social media on consumers' purchase decisions, by providing the perspective of transition economies where social media, due to a slower infrastructure development, still has a potential to grow. Thus, the results obtained in this research could be of great value to SME actors in other developing economies around the world.

This paper is structured as follows: In Section 2, we present the theoretical background of our approach. In the following Section 3, we specify the model within formulated hypotheses. Information about the used materials and methods is provided in Section 4. The empirical results are presented in Section 5, followed by a discussion that includes limitations in Section 6. Finally, our conclusions and practical implications are presented in Section 7.

\section{Theoretical Backgrounds}

As there is no single theory that can be used as the base for answering our research questions, we used a composite approach based on the definition of trust (as a multidimensional construct) [34] and two established theories: trust transfer theory [35] and theory of reasoned action [36].

For an exchange relationship, trust can be defined as one side's belief that the other side will do what was agreed before [37]. Schurr and Ozanne [38] defined trust as a confidence in competences and a readiness of another side to devote itself to the business cause and fulfill its obligations. In broader terms, Mayer et al. [39] defined trust as a readiness to be exposed to actions of another party where the mentioned readiness should be independent of the ability to check that other side.

The trust constructs used in the model were formulated considering Gefen and Straub's [34] explanation of the complex nature of perceived trust. According to it, trust occurs through three factors: ability, integrity and benevolence. These factors are important for trust and related to each other. The authors state, however, that values of these factors can significantly vary at different points in time. Thus, although it is not necessary to have similar value intensities, the presence of all three factors at the recording time is necessary in order to consider them as trust factors. In keeping with the mentioned theoretical basis, trust, for online environments, is a belief formed on the perceived characteristics of another side: ability, integrity and benevolence [40]. These factors are considered within the scales and the questions used to collect data in this research (for more detailed insights about the used scales and questions, please refer to Table A1 in the Appendix A). 
Trust transfer theory represents the second part of the theoretical foundations we based our research on. Trust transfer is recognized as one of the significant mechanisms of trust formation [41]. It is a process that occurs when "the unknown target [is] being perceived as related to the source of the transferred trust" [35] (p. 6).

Shi and Chow [42], based on findings by Campbell [43], pointed out that the necessary relatedness is based on similarity, closeness and common fate. Thus, they find an applicability of the trust transfer approach in an online environment, where companies appear as a part of an online group on a social media page. As part of a (online) group, the company shares similar values with potential and existing customers, inducing the trust transfer process.

eWOM in a social media environment accommodates a trust transfer process, in the direction from other members (experienced consumers) towards a company [44]. In other words, consumers' trust in a company is increased as the company is perceived as part of the same group with more trustful subjects. In the eyes of potential customers, more trustful subjects are other customers who have already tried a product [45].

Thus, the result of the trust transfer process will be observed not only as trust in a particular product or some experience attributes provided by other consumers, but as trust in the information supplied by the company as well. Although a company's claims and consumer reviews can be different by nature (i.e., credence and experience attributes), the sense of a group activity within the dedicated social media page should help build consumers' trust in a company.

The third theoretical part we use is defined as theory of reasoned action (TRA). Due to its primary purpose of understanding a willing behavior of an individual, this theory is recognized as a suitable framework for a research aimed towards relationships between consumers' attitudes, intentions and behaviors [46].

TRA is also considered a sufficient basis for researching the mentioned relationships in the consumers' trust context, as there is no dedicated theory explaining consumer behavior connected to it. [46]. In the literature, TRA has already been used for investigating consequences of trust and the relationship between trust and trust outcomes [46-48]. The same approach will be used here within an "antecedents-trust-outcomes" model form proposed by Lu et al. [44]. This approach lies in the fact that, according to TRA, the expectation about the behavior outcomes (salient beliefs) affects the intention to initiate a particular behavior [49]. Pavlou and Gefen [47] mentioned that trust and perceived risk can be observed as salient beliefs. Therefore, relating to the applicability of TRA, trust can be regarded as the prior cause of people's behavior.

According to TRA, a behavioral intention is the best predictor of an actual behavior [49]. By including behavioral intentions into the analysis, it is possible to extrapolate findings to real-world behavior. Thus, in our research context, purchase intention, as the most important endogenous variable, represents the best predictor of an actual purchase intention at the consumer level. The statement is also valid for two other endogenous variables in the model: intention to obtain information from a company and intention to obtain information from other virtual community (VC) members (a term we use to include anyone other than the company).

\section{Model Specification}

The models that account for the effect of word-of-mouth (WOM) on consumers' behavior can be divided into three groups. The simplest group consists of the first WOM model formulations called The Organic Interconsumer Influence Model [50]. In this case, WOM happens between consumers without any direct encouragement, effect or quantification by companies. The next group, the Linear Marketer Influence Model, starts with research that points out the importance of influential individuals among consumers [50]. This is characterized by active engagement by companies to influence such individuals, which consider the effect they have on other consumers [51]. The third and the newest group of research is The Network Coproduction Model, and it includes Web 2.0 development which 
has provided an opportunity for consumers to quickly interact and share opinions [50]. It also accounts for the participation of companies, as they quickly recognized the importance of that space and got involved [52]. Social media pages founded by companies represent a way for them to participate in an online environment in a more controlled manner [53]. However, the basic specifics of this model are still valid: compared to previous times, new tactics and metrics are applied by companies in order to aim and influence the consumer or opinion leaders. Further, it accounts for the existence of a multidirectional exchange of messages in that environment.

The model we use as the base for our research was formulated by Lu et al. [44]. This model is within the frames defined by the Network Coproduction Model and belongs to the group of models which account for the influence of consumers' trust. Trust is an antecedent of the intention to obtain information (eWOM adoption) and also an antecedent of the value of co-creation in an online environment [54]. As trust is defined as a belief, it can be incorporated in the model form determined by theory of reasoned action (or theory of planned behavior) and used as an antecedent of consumers' purchase intention [55].

We employed a modified version of the model [44], as a way to econometrically prove (by covariance-based structural equation modeling) the research hypotheses using the collected data. The used model uses trust as the central construct and involves 10 constructs in total.

The model also includes the effect of trust antecedents on trust, following the model form "antecedents-trust-outcomes". Following this framework, the antecedent part in our model consists of familiarity, perceived similarity, structural assurances, trust propensity and electronic word-of-mouth (eWOM) (Figure 1). The eWOM part was added considering the importance of positive comments on consumers' attitudes [19]. Regarding trust outcomes, the model includes the intention to obtain information from a company and from other VC members and consumers' purchase intention. The separation of the intention to obtain information from a company and from other VC members represents the second modification of the model. With this modification, we will be able to measure the effect of trust in a company on the intention to obtain information from a company. The importance of such a modification is drawn from the necessary informant role of a company when certifications are not available and credence attributes of products are in question. We also introduced an endogenous covariance between two new factors. In this manner, the model is able to capture the covariance, whose existence is safe to assume because of the shared origin of these factors.

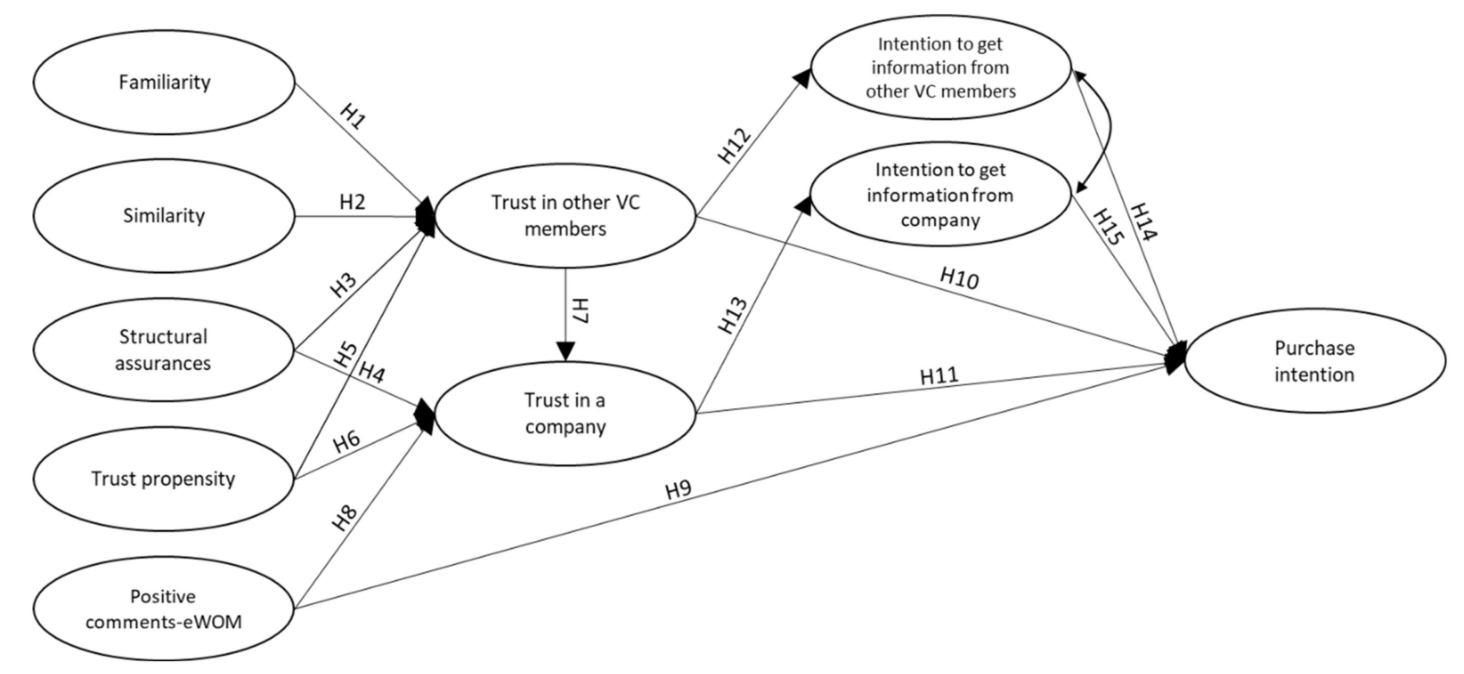

Figure 1. Structural model with hypotheses.

On the side of the trust antecedents, the model considers familiarity as the result of the interactions of individuals (excluding the company or the website administrator). 
Due to this familiarity, an individual can form expectations towards others [56]. These expectations are the source of trust or distrust and therefore antecedents of trust [57]. As Lu et al. [44] emphasized, previous interactions significantly contribute to trust development. Accumulated knowledge gained through interpersonal experience will positively influence trust. In order to verify this claim, H1 was formed.

Hypothesis 1 (H1). Perceived familiarity will positively affect consumers' trust in other VC members.

Grouping people and creating communities have a positive influence on trust. Similarities in groups improve the acceptance of the exchanged information $[40,58]$. Likewise, social media users are prone to communicate with other users similar to them, where shared preferences and similarities are taken into account during the decision process to trust or not [57]. Accordingly, we formulated H2.

Hypothesis 2 (H2). Perceived similarity will positively affect consumers' trust in other VC members.

Structural assurances are beliefs based on conditions and guarantees in a particular situation, which makes success likely [41]. Lu et al. [44] hypothesized that if the website maintains the online rules, it will result in greater confidence, firstly in other VC members, but also in the administrator, the company or the website. Therefore, H3 and H4 will be checked.

Hypothesis 3 (H3). Perceived structural assurances will positively affect trust among other VC members;

Hypothesis 4 (H4). Perceived structural assurances will positively affect consumers' trust in a company.

Reflecting on previous findings [39], it can be supposed that in a social commerce environment, trust propensity is positively related to trust. Trust propensity is the tendency of an individual to believe or not believe in other individuals; it has increased significance in a situation when the trustor is more unfamiliar with the trustee [59]. This relation will be checked through hypotheses $\mathrm{H} 5$ and H6.

Hypothesis 5 (H5). Trust propensity will positively affect trust among other VC members;

Hypothesis 6 (H6). Trust propensity will positively affect consumers' trust in a company.

Lu et al. [44] formulated trust as a latent component regarding trust dimensionality outlined by Mayer et al. [39] that includes three dimensions of trust: ability, integrity and benevolence. The mentioned trust dimensions are consistent in both trust constructs in the model: trust in VC members and trust in a company. The positive relation between these two constructs is defined as a trust transfer [35]. To prove the mentioned relation, H7 was formed.

Hypothesis 7 (H7). Consumers' trust in other VC members will positively affect consumers' trust in a company.

Trust in a company is influenced by the previous behavior of the company and experiences of other members which, in the social media environment, have an opportunity to punish or reward the company through the power of eWOM [44]. The existence of eWOM in the online environment provides fulfillment of a need for expressing satisfaction or dissatisfaction about the product or services $[60,61]$. Within negative or positive eWOM, there is an influence on consumers' trust in a company, globally or, in particular, in the spheres of the company's credibility and benevolence $[19,62,63]$. Thus, as a modification of the model, a latent variable representing positive eWOM was introduced and hypothesis H8 was formed. 
Hypothesis 8 (H8). Positive eWOM will positively affect consumers' trust in a company.

Moreover, eWOM can have a direct influence on the purchase intention [64,65]. Confirmatory to it, previous findings indicate that the purchase intention of a consumer greatly depends on the comments of previous consumers [66]. Purchase intention will be an additional effect of the positive eWOM defined within $\mathrm{H} 9$.

Hypothesis 9 (H9). Positive eWOM will positively affect purchase intention.

Lu et al. [44] differentiated between two trust constructs; both are predecessors of purchase intention in their model. The first one is the consumers' trust in other members of the VC. According to the authors of the model, if there is trust between VC members, the likeliness of purchase is higher. The other construct, consumers' trust in a company, is also positively related to the purchase intention $[19,44]$.

Hypothesis 10 (H10). Trust in other VC members will positively affect purchase intention;

Hypothesis 11 (H11). Trust in the company will positively affect purchase intention.

Lu et al. [44] also acknowledged trust as a predecessor to consumers' intention to obtain information. However, we split that construct into two new constructs: intention to obtain information from other VC members and intention to obtain information from a company. Therefore, conditions were set for estimating the trust influence on the process of information acceptance in conditions where two distinct sources are present: a company and other VC members. This modification was intended to indicate possible ways for achieving higher acceptance of information coming specifically from a company, through the confirmation of two hypotheses:

Hypothesis 12 (H12). Trust in other VC members will positively affect the intention to obtain information from other VC members;

Hypothesis 13 (H13). Trust in a company will positively affect the intention to obtain information from the company.

The model [44] uses suggestions given by Pavlou and Fygenson [67], according to which a consumer visits an online site in search of information. The information there is searched in a cognitive phase of the consumer's need and relates positively to their purchase intention. In other words, social media provides information about the products when a potential buyer knows what they are looking for, and the information found there should positively influence the final purchase intention. According to the introduced modification with separate sources of information, we formed two hypotheses:

Hypothesis 14 (H14). The intention to obtain information from other VC members will positively affect the purchase intention;

Hypothesis 15 (H15). The intention to obtain information from a company will positively affect the purchase intention.

The scales used in the research have been used before (Table A1 in the Appendix A) [19,44]. A scale for constructing familiarity is Lu et al.'s [44] modification of the scale previously introduced by Gefen [68] for familiarity within a web store. The scale for similarity partially originates from Crosby et al.'s [69] research, where similarity was measured under three aspects: appearance, lifestyle and status similarity. Lu et al. [44] modified that scale by keeping only the lifestyle component due to the inapplicability of appearance and status similarity in an online environment. The same authors adapted the structural assurance scale from Gefen et al. [20] 
and the purchase intention scale from Pavlou and Gefen [47]. Trust propensity, intention to obtain information and some parts of the trust constructs were measured with scales adapted from Ridings et al. [70]. Further, measuring trust within its dimensions was conducted with questions originating from Bhattacherjee [71]. Items for measuring the purchase intention were originally used by Pavlou and Gefen [47].

We adapted the scale for intention to obtain information proposed by Lu et al. [44] with respect to the information source in the social media online environment: other consumers and a company. Hence, using slightly modified versions of the questions, we formed two new factors. Moreover, we adopted the scale from Pavlou and Dimoka [62] to measure the perception of positive comments (eWOM), as they have a positive effect on consumers' trust in a company and purchase intentions [19].

\section{Materials and Methods}

\subsection{The Survey}

The survey was conducted in Belgrade, Serbia, during May and June 2019. Students of the University of Belgrade, in teams of 2 or 3, conducted a face-to-face survey in public places. Subjects were asked to fill out a questionnaire on the spot. Questions used in this paper were part of a larger questions set of 72 questions. All questions (Table A1 in the Appendix A) were recorded with a 7-point Likert scale.

In order to make the sample as representative as possible, only persons who actively follow a company on social media were included in the survey. Only those who answered that question in the affirmative were questioned further. Due to the criteria, the age structure in our sample (Table A2 in the Appendix A) expectedly deviated from the age structure of the total population in the country (or in the city of Belgrade, as these two are not significantly different). It should be noted that the age structure of social media users is not an adequate criterion for sample representativeness, as the younger people among them are more often online fans or followers [72]. For our target population, represented by the mentioned subset of social media users, there are no official data, so the sample bias cannot be precisely estimated. The high share of people in their 20s was, however, expected when looking at age structures in similar papers $[19,44]$.

During the process of translation and adaptation, the imperative was to maintain the original questions' meaning. Due to semantic language differences, some questions could not be translated from English to Serbian without losing some of their original meaning. In situations such as these, those questions were not translated and included in the questionnaire, making the dataset and the measuring model more parsimonious. The semantics of the questions were proofed in a two-way approach. Firstly, brainstorming sessions about the questions' meaning between Serbian-speaking co-authors were held. The second step included survey pre-test sessions in small groups of students at the University of Belgrade. In groups of 5, bachelor students answered and commented on their perception of the meaning of each question. Expressing an opinion regarding the questions' semantics was strongly encouraged. In the end, the results from both steps were used as guidelines for writing the final versions of the questions.

Due to the logistical and organizational conditions, conducting the survey was possible in the capital city of Serbia only. With a limited number of surveyors available, including other cities and regions in the sample would have forced the change of the survey type from a face-to-face type to an online type. This idea was rejected because it was assumed that such an approach would cause a low and selective participation [73]. A low participation would likely arise due to the length of the survey [74]. Further, the questions, based on scales aimed for factor analysis, certainly would not have helped the response rates in the online survey either [75]. Considering all these points, our sample is representative of the limited population, as the primary aim was to prove the online trust-building mechanism and its influence on purchase intentions within the defined model.

In total, 1111 persons were included in the questionnaire. Data cleaning was conducted by deleting listwise using several criteria. Firstly, empty recordings and recordings consist- 
ing of all the same entries were removed. Secondly, recordings which had more than $10 \%$ (more than 3) of missing answers were also excluded. Thirdly, recordings with repeated patterns or noticeably illogical answers were subject to deletion too. Therefore, the final sample size significantly shrunk to 737 recordings. It is possible that 72 questions (in the complete questions set) were, for some respondents, too many to answer in public space conditions. Many unfinished questionnaires are confirmatory to this. Moreover, due to the explained conditions, surveyors were unable to check the quality of answers on the spot.

\subsection{Structural Equation Modeling}

In order to analyze data, we used a structural equation modeling approach (SEM). SEM is a category of a multivariate analysis that allows inclusion of unobservable variables in the model. With the SEM, we used several indicators to define each of the unobservable variables (a construct) in the model (Table 1). In this manner, we fulfilled theoretical assumptions about the multifaceted nature of the constructs. Further, including more indicators of the same constructs will lower the measurement error [76]. The theoretical background was used to formulate the constructs, which are mathematically presented as a linear combination of several observable variables (questions).

Table 1. Constructs of the model.

\begin{tabular}{|c|c|c|c|}
\hline Composite Variables & Abbreviation & Indicator Variables & Explanation of the Construct \\
\hline Familiarity & MFTY & $x 1, x 2$ & $\begin{array}{l}\text { Individuals' impression of familiarity with other } \\
\text { members of the virtual community (VC) }\end{array}$ \\
\hline Similarity & MSTY & $x 3, x 4, x 5$ & $\begin{array}{c}\text { Individuals' impression of similarity with other } \\
\text { members of the VC }\end{array}$ \\
\hline Structural assurances & STASS & $x 6, x 7$ & $\begin{array}{l}\text { Individuals' feeling of assurance regarding } \\
\text { privacy while communicating in the VC }\end{array}$ \\
\hline Trust propensity & TPROP & $x 8, x 9, x 10$ & $\begin{array}{c}\text { Individuals' self-assessment about proneness to } \\
\text { trust other persons }\end{array}$ \\
\hline $\begin{array}{l}\text { Positive comments through } \\
\text { eWOM }\end{array}$ & COMM & $x 31, x 32$ & $\begin{array}{l}\text { Individuals' impression of positive consumer } \\
\text { feedback in the comments in the VC }\end{array}$ \\
\hline Trust in other VC members & $\mathrm{TM}$ & - & - \\
\hline \multicolumn{2}{|c|}{-Integrity and benevolence } & $x 11, x 12, x 13$ & $\begin{array}{l}\text { Individuals' impression of integrity and } \\
\text { benevolence of other VC members }\end{array}$ \\
\hline \multicolumn{2}{|l|}{-Ability } & x14, x15 & $\begin{array}{l}\text { Individuals' impression about of ability of other } \\
\text { VC members }\end{array}$ \\
\hline Trust in a company & TC & - & - \\
\hline \multicolumn{2}{|l|}{-Integrity } & $x 16, x 17$ & $\begin{array}{l}\text { Individuals' impression of integrity of } \\
\text { a company }\end{array}$ \\
\hline \multicolumn{2}{|c|}{-Benevolence } & $\mathrm{x} 18, \mathrm{x} 19$ & $\begin{array}{l}\text { Individuals' impression of benevolence of } \\
\text { a company }\end{array}$ \\
\hline \multicolumn{2}{|l|}{-Ability } & $x 20, x 21$ & Individuals' impression of ability of a company \\
\hline $\begin{array}{l}\text { Intention to obtain } \\
\text { information from other } \mathrm{VC} \\
\text { members }\end{array}$ & IGIM & $x 22, x 23, x 24$ & $\begin{array}{l}\text { Individuals' self-assessment of an intention to go } \\
\text { to the social media page in order to find } \\
\text { information originating from other VC members }\end{array}$ \\
\hline $\begin{array}{l}\text { Intention to obtain } \\
\text { information from a company }\end{array}$ & IGIC & $x 25, x 26, x 27$ & $\begin{array}{l}\text { Individuals' self-assessment of an intention to go } \\
\text { to the social media page in order to find } \\
\text { information originating from a company }\end{array}$ \\
\hline Purchase intentions & PINT & $x 28, x 29, x 30$ & $\begin{array}{l}\text { Individuals' self-assessment of an intention to } \\
\text { actually purchase products of the company } \\
\text { he/she follows online }\end{array}$ \\
\hline
\end{tabular}


The composite value of the construct was calculated as a sum of the products of weights and corresponding data observations for the indicator variables. The weight of one indicator is relative to other indicators with whom it shares the same dimension, representing one construct. As there is more than one observation in the sample, a matrix form of the mathematical expression represents the measuring model in SEM.

In the structural part of SEM, we defined a structural model within the research hypotheses. The hypotheses represent the defined relationships among the constructs. Within the SEM, 10 main constructs were simultaneously included as independent or dependent variables in a number of equations, due to the interrelationship between them (Figure 1).

The SEM we used is covariance-based, as this is a justified choice when research is of a more confirmatory nature [77]. A relationship between two constructs, among many others in SEM, where $y=\beta x+\varepsilon$ (presented in the structural model as $X \rightarrow Y$ ), can be explained as

$$
\begin{array}{r}
\operatorname{Cov}(x, y)=E[x y]=E[x(\operatorname{SS} x+\varepsilon)]=E[S S x x+x \varepsilon]=\operatorname{SSE}[x x]+E[x \varepsilon]=\operatorname{SSCov}(x, x)+\operatorname{Cov}(x, \varepsilon) \\
\text { With } \operatorname{Cov}(x, \varepsilon)=0 ; \\
\operatorname{Cov}(x, y)=\operatorname{SSCov}(x, x)=\operatorname{SSVar}(x) ; \operatorname{SS}=(\operatorname{Cov}(x, y)) /(\operatorname{Var}(x))
\end{array}
$$

\section{Results}

A table with factor loadings was calculated using R software (Table 2). According to the theorized model, 10 factors were set, and Promax rotation was used. We treated all of the constructs as unidimensional, as all of them were loaded on proper factors from the beginning. Furthermore, discrete validity and other measurements had significantly better values than in the case of treating the model as a second order model because of the trust constructs. Eigenvalues for all 10 extracted factors were above 1 . The final results of the factor analysis are presented in Table 2.

The result of Bartlett's test was highly significant at a $p<0.001$ level, confirming the dataset's suitability for factor analysis. Further, sampling adequacy was confirmed with a Kaiser-Meyer-Olkin (KMO) index value of $0.94[78,79]$. This result is noticeably above Kaiser's [79] threshold of 0.5, and it describes the dataset's adequacy for factor analysis as "superb" [80]. After the factor analysis, most of the loadings were above the recommended level of 0.7 [76]. Regarding the lower loadings (0.48 to 0.54$)$, they appeared at trust indicators which are also a part of a sub-factor in the main factor (Table 2). Besides that fact, these indicators were still far from the minimum threshold of 0.3 to 0.4 [76].

It was estimated that the 10 extracted factors explain about $68 \%$ of the variance (Table 2). On the other hand, the percentage of the explained variance in the analysis using one factor is $38 \%$. This result passes Harman's single factor test-there is no common method bias in the dataset [81].

The internal consistency reliability of the constructs is confirmed with Cronbach's alpha values presented in Table $3[82,83]$. To conduct a convergent validity check, composite reliability (CR) and average variance extracted (AVE) scores were estimated. CR and AVE were estimated within a formula given by Fornell and Larcker [84]. All constructs fulfill the conditions of $>0.7$ and $>0.5$, for CR and AVE. 
Table 2. Factor loadings (for abbreviations, please refer to Table 1).

\begin{tabular}{|c|c|c|c|c|c|c|c|c|c|c|}
\hline & TC & TM & MSTY & IGIM & TPROP & IGIC & PINT & MFTY & STASS & COMM \\
\hline $\mathrm{x} 1$ & 0.06 & -0.01 & -0.04 & 0.01 & -0.01 & 0.01 & 0.02 & 0.91 & 0.08 & -0.01 \\
\hline$x 2$ & 0 & -0.04 & 0.09 & 0 & 0.03 & 0.03 & 0.05 & 0.78 & 0.04 & 0 \\
\hline $\mathrm{x} 3$ & 0.08 & -0.02 & 0.71 & 0.05 & -0.02 & 0.02 & -0.03 & 0 & -0.03 & 0.09 \\
\hline$x 4$ & 0 & 0.07 & 0.93 & 0.01 & 0 & -0.08 & 0.03 & 0.01 & -0.1 & -0.05 \\
\hline $\mathrm{x} 5$ & -0.03 & 0.02 & 0.85 & -0.01 & 0 & 0.03 & -0.01 & 0.02 & 0 & -0.03 \\
\hline$x 6$ & -0.01 & -0.01 & -0.13 & 0 & -0.02 & 0.05 & -0.01 & 0.01 & 0.92 & 0.04 \\
\hline$x 7$ & 0.05 & 0.05 & 0.02 & 0.03 & 0.02 & -0.09 & -0.05 & 0.14 & 0.73 & -0.04 \\
\hline $\mathrm{x} 8$ & 0.05 & -0.08 & 0.02 & 0.07 & 0.81 & -0.01 & -0.02 & -0.12 & 0.08 & 0.04 \\
\hline $\mathrm{x} 9$ & 0.01 & 0.02 & -0.02 & -0.03 & 0.87 & 0 & 0 & 0.09 & -0.09 & 0 \\
\hline$x 10$ & -0.06 & 0.04 & -0.02 & -0.03 & 0.83 & 0.02 & 0.02 & 0.03 & 0 & -0.03 \\
\hline x11 & 0 & 0.52 & 0.22 & -0.03 & 0.01 & 0.03 & -0.05 & 0.06 & 0.09 & 0.01 \\
\hline$x 12$ & 0.03 & 0.59 & 0.16 & 0 & 0.04 & 0.06 & -0.05 & 0 & -0.01 & -0.01 \\
\hline x13 & 0.02 & 0.72 & -0.06 & 0.1 & -0.01 & 0.01 & 0 & 0.02 & 0.05 & -0.01 \\
\hline x14 & -0.03 & 1 & -0.09 & -0.04 & -0.02 & 0 & 0.01 & -0.07 & 0 & 0 \\
\hline x15 & 0.06 & 0.77 & 0 & -0.05 & 0 & -0.04 & 0.08 & -0.01 & -0.05 & 0.05 \\
\hline x16 & 0.78 & -0.01 & 0.09 & -0.02 & 0 & -0.05 & 0.08 & 0.01 & -0.02 & -0.05 \\
\hline x17 & 0.85 & 0.07 & -0.09 & 0.01 & 0.02 & -0.1 & 0.11 & 0.03 & -0.05 & -0.03 \\
\hline x18 & 0.99 & 0.02 & -0.14 & -0.01 & -0.02 & 0.03 & -0.07 & 0.13 & -0.12 & 0.01 \\
\hline x19 & 0.78 & -0.02 & 0.02 & 0.01 & 0.01 & 0.09 & -0.16 & 0.02 & -0.03 & 0.08 \\
\hline$x 20$ & 0.51 & -0.09 & 0.14 & -0.04 & -0.01 & 0.05 & 0.06 & -0.05 & 0.19 & 0.01 \\
\hline$x 21$ & 0.48 & 0.05 & 0.06 & -0.01 & -0.01 & 0.03 & 0.09 & -0.21 & 0.24 & -0.02 \\
\hline$x 22$ & 0.01 & 0 & 0.04 & 0.84 & 0.01 & -0.05 & 0.03 & 0.03 & -0.03 & -0.02 \\
\hline$x 23$ & -0.01 & 0.01 & -0.01 & 0.91 & 0 & -0.02 & 0.01 & -0.06 & 0.05 & -0.02 \\
\hline$x 24$ & -0.03 & -0.03 & -0.01 & 0.72 & -0.02 & 0.08 & 0.02 & 0.04 & 0.01 & 0.07 \\
\hline$x 25$ & 0.08 & 0.09 & -0.03 & 0.17 & -0.01 & 0.71 & -0.07 & -0.03 & -0.06 & -0.08 \\
\hline$x 26$ & 0.02 & -0.11 & 0.03 & -0.03 & 0 & 0.92 & -0.03 & 0.02 & 0.03 & 0.01 \\
\hline$x 27$ & -0.07 & 0.08 & -0.05 & -0.11 & 0.02 & 0.75 & 0.07 & 0.06 & 0 & 0.05 \\
\hline$x 28$ & -0.02 & -0.06 & 0.05 & -0.03 & 0 & 0.32 & 0.54 & -0.02 & 0.03 & -0.01 \\
\hline$x 29$ & 0.02 & 0.06 & -0.04 & 0.09 & 0.02 & -0.05 & 0.78 & 0.05 & -0.07 & 0 \\
\hline x30 & 0.02 & 0.01 & 0.01 & -0.01 & -0.01 & -0.02 & 0.81 & 0.02 & 0.01 & 0.02 \\
\hline X31 & 0 & 0.05 & -0.02 & -0.01 & 0 & -0.01 & 0.01 & -0.02 & 0.02 & 0.9 \\
\hline X32 & 0.01 & 0.16 & 0 & 0.03 & 0 & -0.02 & 0.02 & 0.01 & -0.01 & 0.71 \\
\hline Eigenvalues & 3.57 & 3.05 & 2.27 & 2.17 & 2.12 & 2.13 & 1.81 & 1.67 & 1.51 & 1.47 \\
\hline $\begin{array}{c}\text { Proportion of } \\
\text { variance explained }\end{array}$ & 0.11 & 0.1 & 0.07 & 0.07 & 0.07 & 0.07 & 0.06 & 0.05 & 0.05 & 0.05 \\
\hline $\begin{array}{c}\text { Cumulative } \\
\text { proportion of } \\
\text { variance explained }\end{array}$ & 0.11 & 0.21 & 0.28 & 0.35 & 0.41 & 0.48 & 0.53 & 0.59 & 0.63 & 0.68 \\
\hline
\end{tabular}

Table 3. Assessment of the measurement model for the constructs.

\begin{tabular}{ccccc}
\hline Constructs & $\begin{array}{c}\text { Cronbach's } \\
\text { Alpha }\end{array}$ & CR & AVE & Std. Loadings \\
\hline MFTY & - & 0.84 & 0.72 & $\times 1(0.91) \times 2(0.78)$ \\
MSTY & 0.87 & 0.87 & 0.70 & $\times 3(0.71) \times 4(0.93) \times 5(0.85)$ \\
STASS & - & 0.81 & 0.69 & $\times 6(0.92) \times 7(0.73)$ \\
TPROP & 0.87 & 0.88 & 0.70 & $\times 8(0.81) \times 9(0.87) \times 10(0.83)$ \\
TM & 0.88 & 0.85 & 0.55 & $\times 11(0.52) \times 12(0.59) \times 13(0.72) \times 14$ \\
& & & & $(1.00) \times 15(0.77)$ \\
TC & 0.90 & 0.88 & 0.57 & $\times 16(0.78) \times 17(0.85) \times 18(0.99) \times 19$ \\
IGIM & 0.87 & 0.87 & 0.68 & $\times 22(0.84) \times 23(0.91) \times 24(0.72)$ \\
IGIC & 0.83 & 0.84 & 0.64 & $\times 25(0.71) \times 26(0.92) \times 27(0.75)$ \\
PINT & 0.83 & 0.76 & 0.52 & $\times 28(0.54) \times 29(0.78) \times 30(0.81)$ \\
COMM & - & 0.79 & 0.66 & $\times 31(0.9) \times 32(0.71)$ \\
\hline
\end{tabular}


Discriminant validity was estimated using the Fornell-Larcker criterion and heterotraitmonotrait (HTMT) ratio (Tables 4 and 5). The Fornell-Larcker criterion for discriminant validity has been fulfilled. Additionally, the HTMT ratio was used. The HTMT ratio is described as a new emerging discriminant validity criterion because it arguably represents the best compromise between high sensitivity and low arbitrary violation (i.e., false positive) rates [85]. Voorhees et al. [86] showed its usefulness in covariance-based structural equation modeling (CB-SEM) as well. Thus, in line with their recommendations given for determining discriminant validity in marketing, the HTMT ratio was also used: all values are below the threshold of 0.85 , also confirming the discriminant validity $[85,86]$.

Table 4. Correlation matrix and square roots of average variances extracted (AVEs) (Fornell-Larecker criterion).

\begin{tabular}{cccccccccc}
\hline & TC & TM & MSTY & IGIM & TPROP & IGIC & PINT & MFTY & STASS \\
\hline TC & $\mathbf{0 . 7 5}$ & & & & & & & & \\
TM & 0.62 & $\mathbf{0 . 7 4}$ & & & & & & & \\
MSTY & 0.68 & 0.72 & $\mathbf{0 . 8 3}$ & & & & & & \\
IGIM & 0.45 & 0.51 & 0.55 & $\mathbf{0 . 8 3}$ & & & & & \\
TPROP & 0.38 & 0.44 & 0.42 & 0.26 & $\mathbf{0 . 8 4}$ & & & & \\
IGIC & 0.54 & 0.50 & 0.50 & 0.49 & 0.33 & $\mathbf{0 . 8 0}$ & & & \\
PINT & 0.56 & 0.55 & 0.55 & 0.49 & 0.34 & 0.65 & $\mathbf{0 . 7 2}$ & & \\
MFTY & 0.30 & 0.48 & 0.45 & 0.34 & 0.48 & 0.34 & 0.35 & $\mathbf{0 . 8 5}$ & \\
STASS & 0.67 & 0.52 & 0.63 & 0.39 & 0.33 & 0.44 & 0.47 & 0.21 & $\mathbf{0 . 8 3}$ \\
COMM & 0.50 & 0.68 & 0.55 & 0.48 & 0.35 & 0.42 & 0.51 & 0.31 & 0.41 \\
\hline
\end{tabular}

Table 5. Heterotrait-monotrait (HTMT) ratio.

\begin{tabular}{cccccccccc}
\hline & TC & TM & MSTY & IGIM & TPROP & IGIC & PINT & MFTY & STASS \\
\hline TC & & & & & & & & & \\
TM & 0.67 & & & & & & & & \\
MSTY & 0.69 & 0.77 & & & & & & \\
IGIM & 0.46 & 0.54 & 0.58 & & & & & \\
TPROP & 0.38 & 0.45 & 0.42 & 0.27 & & & & \\
IGIC & 0.56 & 0.54 & 0.50 & 0.51 & 0.35 & & & \\
PINT & 0.61 & 0.61 & 0.59 & 0.56 & 0.37 & 0.72 & & & \\
MFTY & 0.40 & 0.54 & 0.54 & 0.40 & 0.51 & 0.43 & 0.47 & & \\
STASS & 0.70 & 0.57 & 0.60 & 0.41 & 0.35 & 0.43 & 0.48 & 0.37 & \\
COMM & 0.55 & 0.76 & 0.60 & 0.52 & 0.37 & 0.45 & 0.57 & 0.39 & 0.45 \\
\hline
\end{tabular}

We tested our research model within the formulated hypotheses. Significant relationships between trust in other VC members (TM) and, on the antecedent side, familiarity (MFTY) (SS = 0.107, $p<0.01)$, similarity (MSTY) $(\mathrm{SS}=0.649, p<0.001)$, structural assurances (STASS) (SS $=0.116, p<0.01)$ and trust propensity (TPROP) $(\mathrm{SS}=0.093, p<0.01)$ support hypotheses H1, H2, H3 and H5. The path between TM and trust in a company (TC) was also significant, supporting the $\mathrm{H} 7$ hypothesis about the existence of a trust transfer process (SS $=0.361, p<0.001)$. Similarly, significant paths between STASS and TC $(\mathrm{SS}=0.433$, $p<0.001)$ and between positive comments through eWOM (COMM) and TC (SS = 0.091, $p<0.05)$ support hypotheses $\mathrm{H} 4$ and $\mathrm{H} 8$.

Hypotheses that describe direct effects of TM and TC, H10, H11, H12 and H13, are supported too. In the case of TM, this is proven by significant paths towards intention to obtain information from other VC members (IGIM) (SS $=0.550, p<0.001)$ and purchase intentions (PINT) (SS = 0.125, $p<0.05)$. For TC, significant paths to intention to obtain information from a company (IGIC) $(\mathrm{SS}=0.552, p<0.001)$ and PINT $(\mathrm{SS}=0.156, p<0.01)$ support the related hypotheses (H13, H11).

The influence of the rest of the factors that positively affect the purchase intention was defined with hypotheses H9, H14 and H15, and they are supported by significant 
paths of COMM to PINT (SS $=0.180, p<0.001$ ), IGIM to PINT (SS $=0.135, p<0.01$ ) and IGIC to PINT (SS $=0.409, p<0.001)$. The only path which appeared insignificant in the model was the path TPROP-TC (SS $=0.039, p=0.257$ ) described by hypothesis H7. This insignificant path was omitted and the model was estimated again (Figure 2). Values of absolute, incremental and parsimonious fit measures are shown in Table 6.

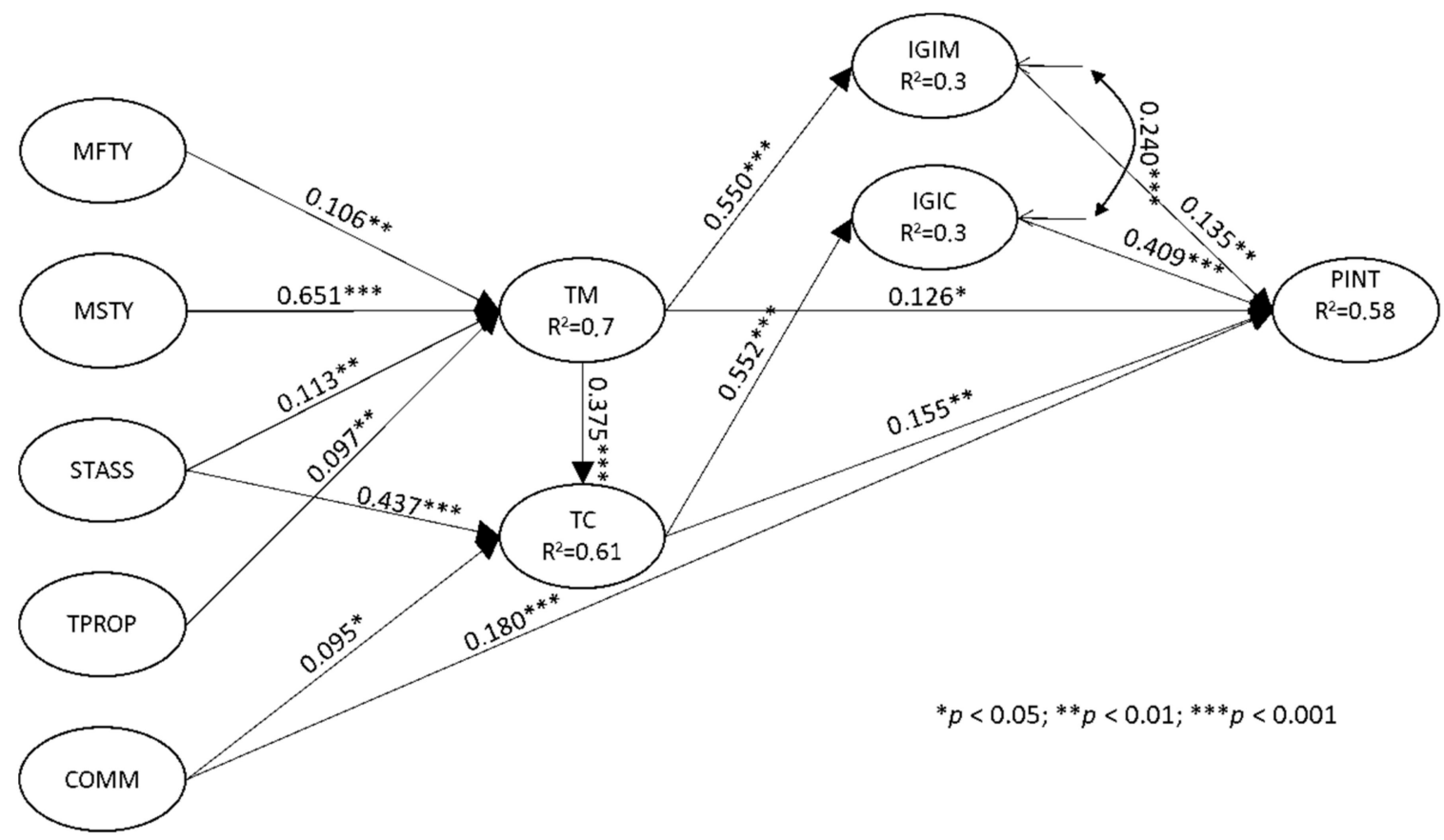

Figure 2. Standardized model solution.

Table 6. Model fit indices and their thresholds of acceptance.

\begin{tabular}{ccccc}
\hline Name of the Category & Name of the Index & Index Name & Level of Acceptance & Values \\
\hline \multirow{2}{*}{ Absolute fit } & Chisq & Discrepancy Chi-Square & $p>0.05$ & 0.0000 \\
\cline { 2 - 5 } & RMSEA & $\begin{array}{c}\text { Root Mean Square of Error } \\
\text { Approximation }\end{array}$ & $<0.08$ & 0.057 \\
\hline \multirow{2}{*}{ Incremental fit } & CFI & Comparative Fit Index & $>0.9$ & $>0.931$ \\
\cline { 2 - 5 } & TLI & Tucker-Lewis Index & $<0.9$ & 3.36 \\
\hline Parsimonious fit & Chisq/df & Chi-Square/Degree of freedom & $<5.0$ & 322 \\
\hline
\end{tabular}

All fit indices fulfill the defined thresholds, except the $p$-value, which is below the conservative condition of the value $\geq 0.05$. Nevertheless, the model fit can be described as good, due to the unsuitability of using that criterion as the basis for acceptance or rejection of the model, especially for larger samples [87].

Beside the direct effects defined with the hypotheses, we used the advantages of structural equation modeling to investigate indirect effects too. We took the TM as the starting point of the indirect path to include and identify the mediation role of the already confirmed trust transfer process path (TM-TC) on PINT. The next indirect path we considered was the path starting with the COMM construct. In this manner, we aimed to confirm complimentary effects to the trust transfer process: besides the direct influence of positive comments on the purchase intention, they also help the trust in a company and can therefore have a mediated positive influence on purchase intentions too.

As a precondition for testing indirect effects, we used the second and third criteria from the well-known set of four given by Baron and Kenny [88]. The reason for that was due to previous results of the methodical checks using simulated data, which showed 
that the reduced set of criteria was regularly better performing than the full set $[89,90]$. According to the reduced set of criteria, there were cues for further investigating indirect effects between TM and PINT (Figure 3) and between COMM and PINT, too.

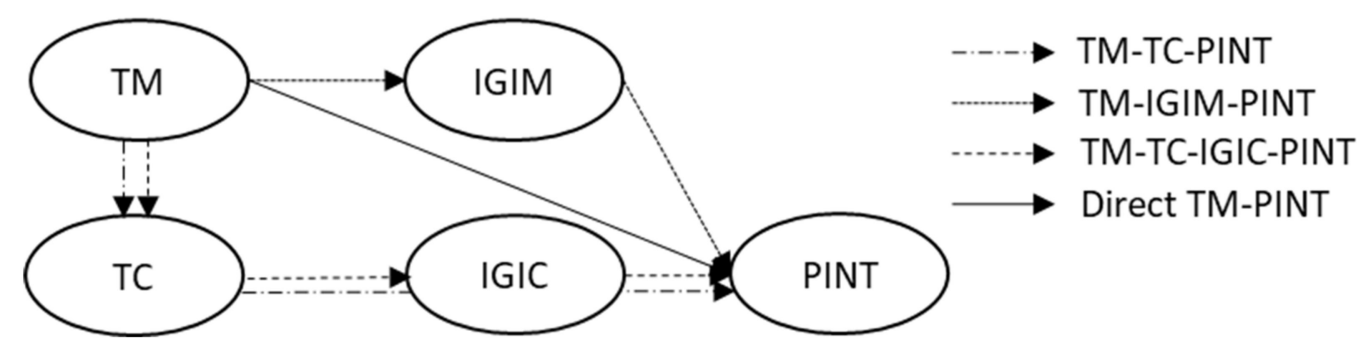

Figure 3. Graphical representation of the examined indirect paths.

In the analysis of the mediated effects, 10,000 bootstrapped samples were drawn. The confidence intervals were bootstrapped as their asymmetry was thought out [91]. However, the bias-corrected bootstrap procedure recommended by MacKinnon et al. [91] was avoided, due to its proneness towards type I errors [92], and also according to the recommendations from [93]. Indirect effects were identified only in the case of examining paths between TM and PINT (for a detailed result of the indirect analysis of paths between COMM and PINT, please refer to Table A3 in the Appendix A).

When tested using bootstrapped standard errors and bootstrapped confidence intervals, all indirect paths from TM to PINT were proven to be significant. The calculated confidence intervals for indirect paths TM-TC-PINT, TM-IGIM-PINT and TM-TC-IGICPINT are, respectively, 95\% CI [0.007, 0.109], 95\% CI [0.009, 0.140] and 95\% CI [0.040, 0.129]. At the same time, the direct effect of TM on PINT was non-significant, 95\% CI [-0.032, 0.284]. Therefore, every indirect path from TM to PINT can be described as a full mediation.

\section{Discussion}

The hypothesized positive relationship between two trust constructs and most of the corresponding trust antecedents is confirmed. To begin with, trust in other VC members on social media is being carried out with perceived familiarity. Hence, previous findings by Lu et al. [44] and Gefen and Straub [34] are confirmed. Similarities between members have also been proven to be in a positive relationship with trust towards VC members.

As far as structural assurances are concerned, a positive relationship is shown in both succeeding constructs-trust in other VC members and trust in a company. However, although in line with findings by Pavlou and Gefen [47], this result is different from results by $\mathrm{Lu}$ et al. [44]. Their research showed only a positive relationship between structural assurances and consumers' trust in other VC members on social media, but not in a company as well. Lu et al. [44] explained that the lack of the relationship between structural assurances and the trust in a company might be caused by including only a sense of security from impersonal structures in the questions. Since we used the same scale in the research, the different result could not be caused by an inclusion of additional personal security senses. However, qualitative analysis of the online activities of the companies mentioned in the survey has shown that a majority of the individuals in our sample assessed the information shared by companies via popular social media services. Compared to Lu et al.'s [44] research, this is substantially different because their respondents were members of a dedicated online selling website. In our research setting, the everyday familiarity with social media, and the well-known structural assurances about it, could positively influence trust towards the company which uses it as a communication medium.

Personal attitudes (trust propensity) have a significant influence on people's trust in other VC members, but not on their trust in a company. Therefore, previous studies [44,70] are only partially proven in this case. The additional exogenous construct introduced by us, positive eWOM, positively influences trust in a company and confirms previous findings $[62,94]$. 
Between the two trust constructs, there is a positive relationship, reflecting the existence of the hypothesized trust transfer [35]. An individual's intention to obtain information showed to be in a positive relationship with the corresponding trust constructs. Findings by Ridings et al. [70] are confirmed, and it is shown that, corresponding with the differentiation of the trust constructs, the construct of intention to obtain information can be divided by information sources. It was possible to analyze the social media webpage environment as a heterogeneous information provider-a virtual space where different subjects with diverse consumer trust levels exist, just as they exist in reality. Lastly, purchase intention is positively affected by positive eWOM, trust in VC members, trust in a company and intention to obtain information from other $\mathrm{VC}$ members as well as from a company.

The mediated effects of trust in other VC members on purchase intentions have proven the importance of the trust transfer process. The path which represents it (TM-TC) is the first and the mutual part in two out of three statistically significant indirect effect paths towards purchase intentions (Table 7). The first of the two (TM-TC-PINT) proves the role of the trust transfer in increasing consumers' trust in the company, which further positively affects the purchase intention. The second path (TM-TC-IGIC-PINT) also confirms its influence on trust in the company. This further helps consumers in perceiving a company as an information provider, which increases their purchase intention. The third significant path, which originates from the trust put in other VC members, includes the informative role of the other VC members and its influence on the purchase intention.

Table 7. Analysis of indirect effects of trust in other VC members (TM) on purchase intentions (PINT).

\begin{tabular}{|c|c|c|c|c|c|}
\hline \multirow{2}{*}{$\begin{array}{l}\text { Indirect Effects of TM on PINT } \\
\text { (Standardized) }\end{array}$} & \multirow{2}{*}{$p$ Values } & \multirow{2}{*}{ S.E. } & \multicolumn{3}{|c|}{ Confidence Intervals } \\
\hline & & & $-2.5 \%$ & SS Estimate & $2.5 \%$ \\
\hline Total & 0.000 & 0.069 & 0.206 & 0.343 & 0.479 \\
\hline Total indirect & 0.000 & 0.046 & 0.127 & 0.217 & 0.306 \\
\hline \multicolumn{6}{|c|}{ Specific indirect } \\
\hline TM-TC-PINT & 0.026 & 0.026 & 0.007 & 0.058 & 0.109 \\
\hline TM-IGIM-PINT & 0.026 & 0.033 & 0.009 & 0.074 & 0.140 \\
\hline TM-TC-IGIC-PINT & 0.000 & 0.023 & 0.040 & 0.085 & 0.129 \\
\hline Direct TM-PINT & 0.118 & 0.081 & -0.032 & 0.126 & 0.284 \\
\hline
\end{tabular}

On the other hand, the lack of a mediated effect between positive comments and purchase intention is somehow contradictory to the theoretical background, as it was supposed that the consumers' positive feedback was the carrier of the trust transfer. Further, according to the results of the main structural model, positive comments influence trust towards a company at a less significant level compared to their effect on purchase intention (Figure 2). We believe that the explanation might be found in the effects not covered by the data collection: the consumers' sense of transparency and value co-creation [95]. Regarding the transparency, there are already developed approaches for dealing, online, with inevitable negative consumer feedback, in ways that do not harm consumers' trust [96]. Therefore, it is possible that the decisional role, at the consumer level, has the overall impression of the company's transparency, regarding both good and bad sides of their products. We can expect that this is connected to the value co-creation which was already proven to be present and influential on consumers' trust in similar online environments [97]. As the respondents were not asked for how long they were following a particular web page, it is very possible that they were already more or less an active part of the value co-creation (at least only as followers). In such a case, they appreciate the mutual aim of making products better [98], even when that includes negative comments. Joining a brand community, according to social identity theory, is a fulfillment of identification with a group $[99,100]$. As it was already explained, according to eWOM theory, other consumers are a more trustable source compared to a company, so the inclusion of it as part of the community group enables the trust transfer process. To recap, trust in a company is not 
built by positive judgments of the more trustworthy subjects, but by regarding the company as a part of a trustworthy group, involved in value creation.

\section{Limitations}

To fulfill the sample size requirements, it was not possible to focus on one dedicated social media platform, company or product. Therefore, a less specific analysis has been made possible within the trade-off. Due to the different platforms, economic subjects and products in question, it is possible that some discrepancies may arise and slightly influence the estimates.

The representativeness of the sample is restricted to young persons who are social media users (online followers) and reside in the capital of Serbia, Belgrade. As we explained in the methodical part, we intentionally restricted the range of the sample representativeness in order to collect a sufficient number of valid answers that can confirm the defined hypotheses.

\section{Conclusions}

The conducted research mostly confirmed the supposed trust-building mechanism in an online environment and its hypothesized relation to the purchase decision. Regarding the determinants of trust between other VC members, the influence of familiarity, similarity and structural assurances was confirmed. When it comes to trust in a company, the same was confirmed for structural assurances and positive comments. Furthermore, the positive relation between trust between other VC members and trust in a company, defined as a trust transfer process, was also confirmed to be a part of the trust-building mechanism.

The direct effect of eWOM on consumers' purchase intentions was also confirmed. When accounting for the effects of the potentially increased trust in a company, it was confirmed that it significantly affects purchase intentions. This also occurs indirectly, through the intention to obtain information.

Overall, the usability of the results goes hand in hand with a depicted situation where an added value of products is present and a company is the only source of information. Thus, these results should be considered as the basis for formulating modern online marketing strategies for SMEs. By utilizing the online environment, trust antecedents can be nurtured in modern conditions where consumer preferences progressively change to credence attributes. This is especially applicable in the area of food products, where added-value is predominantly obtained through credence attributes which often outgrow the range of the existing certification schemes.

In offering an environment where experienced consumers can freely share their opinions, practical implications for SMEs develop in three ways. Firstly, positive comments will have a positive direct influence on purchase intentions. In accordance with the results, consumers will consider other consumers as a relevant source of information and their purchase decisions will be under the direct influence of the received information.

Secondly, positive comments and other trust determinants have an underlying dimension that allows for the building of trust in a company, which represents a useful tool for SMEs for increasing competitiveness in the market. With increased consumer trust, SMEs are more effective in transferring information about credence attributes to customers. Successively, the higher acceptability of the information at the consumer level ensures obtaining planned price premiums for distinct credence attributes of a product.

Thirdly, within the provided transparency, the trust transfer process goes beyond building trust in a company based on only positive comments. Although comments directly influence trust in a company, and especially purchase intentions, their role is not crucial. The analysis of mediated effects showed that the effect of comments on purchase intentions is not carried through the trust in a company. This sheds light on another dimension in the trust-building process, which diminishes the mentioned mediated effect. This dimension includes consumers' perception of a company as a valuable member of the online community, with the same aims as the other VC members. Accordingly, trust 
can be built on the basis of value co-creation, where the company would be a part of the trustworthy online community. If they are well managed, it is likely that negative comments will not have a decisive effect on the level of trust in a company. Practically, companies should treat negative comments as information about a problem that should be jointly solved. Such an approach provides the opportunity to ignite the value co-creation process, which increases consumers' trust in the company and, further, purchase intentions. Moreover, companies should move away from directly addressing negative comments with opposing claims, which is likely counter-effective, as consumers' trust in other consumers is higher than in a company.

Therefore, future marketing strategies should strongly consider creating transparent, dynamic and open online communities, followed by a company's active engagement there. We believe that such an approach would be highly compatible and beneficial for the effectiveness of already present legislative actions that favor production of credence-based products. With suitable marketing campaigns, it would be possible to create increased trust towards a company in the form of purchase intentions at the consumer level, ensuring necessary price premiums for SMEs.

Author Contributions: Conceptualization, B.R. and I.Đ.; data curation, V.Z.; formal analysis, B.R.; investigation, B.R. and I.Đ.; methodology, B.R.; resources, V.Z.; supervision, I.Đ. and T.G.; validation, I.Đ., V.Z. and T.G.; visualization, B.R.; writing—original draft, B.R.; writing—review and editing, B.R., I.Đ., V.Z. and T.G. All authors have read and agreed to the published version of the manuscript.

Funding: This research was funded by the German Academic Exchange Service (DAAD), grant number 57381412, and the publication of this article was funded by the Open Access Fund of the Leibniz Association.

Institutional Review Board Statement: The study was conducted according to the guidelines of the Declaration of Helsinki, and approved by Ethics Committee of Leibniz Institute of Agricultural Development in Transition Economies (IAMO) (2/2019, 26.4.2019).

Informed Consent Statement: Informed consent was obtained from all subjects involved in the study.

Data Availability Statement: The data presented in this study are available on request from the authors.

Conflicts of Interest: The authors declare no conflict of interest.

\section{Appendix A}

Table A1. Questions used in the questionnaire.

\begin{tabular}{lcc}
\hline \multicolumn{1}{c}{ Constructs } & Mean & Std. Deviation \\
\hline $\begin{array}{l}\text { I become familiar with the identities of some members through reading posts, posting, or } \\
\text { replying to messages in the social commerce community. }\end{array}$ & 4.73 \\
\hline $\begin{array}{l}\text { I become familiar with the interests and behavioral characteristics of some members, such } \\
\text { as their writing styles, through reading, posting, or replying to messages in the social } \\
\text { commerce community. }\end{array}$ & 4.75 \\
\hline \multicolumn{1}{c}{ Similarity } & 1.60 \\
\hline $\begin{array}{l}\text { I feel that other VC members have similar interests to mine } \\
\text { I feel that other VC members have similar values to mine. }\end{array}$ & 5.15 \\
\hline I feel that other VC members have similar experience to mine. & 5.11 \\
\hline
\end{tabular}


Table A1. Cont.

\begin{tabular}{|c|c|c|}
\hline Constructs & Mean & Std. Deviation \\
\hline \multicolumn{3}{|l|}{ Structural assurances } \\
\hline $\begin{array}{l}\text { I feel safe communicating with other members because the VC platform provides Internet } \\
\text { safety alerts. }\end{array}$ & 5.14 & 1.37 \\
\hline $\begin{array}{l}\text { I feel safe communicating with other members because I the accessed social commerce } \\
\text { community through a well-known medium. }\end{array}$ & 5.15 & 1.34 \\
\hline \multicolumn{3}{|l|}{ Trust propensity } \\
\hline I generally have faith in humanity. & 5.19 & 1.43 \\
\hline I feel that people are generally reliable. & 4.79 & 1.55 \\
\hline I generally trust other people unless they give me reason not to. & 4.99 & 1.52 \\
\hline \multicolumn{3}{|l|}{ Trust in other VC members' integrity and benevolence } \\
\hline The other VC members would not knowingly do anything to disrupt the conversation. & 4.95 & 1.32 \\
\hline The other VC members are concerned about what is important to others. & 5.16 & 1.25 \\
\hline The other VC members will do everything within their capacity to help others. & 5.03 & 1.23 \\
\hline \multicolumn{3}{|l|}{ Trust in other VC members' ability } \\
\hline $\begin{array}{l}\text { The other VC members have specialized capabilities that can add to the conversation in } \\
\text { this community. }\end{array}$ & 5.17 & 1.14 \\
\hline The other VC members are well qualified in the topics we discuss. & 5.17 & 1.22 \\
\hline \multicolumn{3}{|l|}{ Trust in the company's integrity } \\
\hline Promises made by the company/manufacturer/brand are likely to be reliable. & 5.12 & 5.15 \\
\hline The company/manufacturer/brand is sincere and reliable. & 1.26 & 1.23 \\
\hline \multicolumn{3}{|l|}{ Trust in the company's benevolence } \\
\hline The company/manufacturer/brand is interested in my well-being. & 5.20 & 5.33 \\
\hline I expect that the company's/manufacturer's/brand's intentions are benevolent. & 1.27 & 1.25 \\
\hline \multicolumn{3}{|l|}{ Trust in the company's ability } \\
\hline The company/manufacturer/brand is competent and effective. & 5.35 & 1.18 \\
\hline The company/manufacturer/brand knows about the product. & 5.44 & 1.22 \\
\hline \multicolumn{3}{|l|}{ Intention to get information from the other VC members } \\
\hline $\begin{array}{l}\text { I intend to come to the VC to get related information from the consumers, when I want to } \\
\text { purchase some products. }\end{array}$ & 5.28 & 1.36 \\
\hline $\begin{array}{l}\text { I intend to come to the VC to get provided information by the consumers when I need to } \\
\text { know the characteristics of some products. }\end{array}$ & 5.31 & 1.28 \\
\hline $\begin{array}{l}\text { I will consider coming to the VC to get related information when I need to know other } \\
\text { people's experiences with the products. }\end{array}$ & 5.24 & 1.24 \\
\hline \multicolumn{3}{|l|}{ Intention to get information from the company } \\
\hline $\begin{array}{l}\text { I intend to come to the VC to get related information from the company or the producer } \\
\text { when I want to purchase some products. }\end{array}$ & 5.20 & 1.25 \\
\hline $\begin{array}{l}\text { I intend to come to the VC to get company-provided information when I need to know } \\
\text { the characteristics of some products. }\end{array}$ & 5.22 & 1.23 \\
\hline $\begin{array}{l}\text { I will consider coming to the VC to get related information when I need to know } \\
\text { information which the company provides. }\end{array}$ & 5.23 & 1.24 \\
\hline
\end{tabular}


Table A1. Cont.

\begin{tabular}{lcc}
\hline \multicolumn{1}{c}{ Constructs } & Mean & Std. Deviation \\
\hline \multicolumn{1}{c}{ Purchase intention } & \\
\hline Given the chance, I would consider purchasing products presented in the VC in the future. & 5.27 & 5.17 \\
\hline It is likely that I will actually purchase products presented in the VC in the near future. & 5.27 & 1.16 \\
\hline Given the opportunity, I intend to purchase products presented in the VC. & 5.26 & 1.18 \\
\hline \multicolumn{2}{c}{ Positive comments (eWOM) } & 5.28 \\
\hline $\begin{array}{l}\text { Overall, the comments on the company/manufacturer/brand social media page } \\
\text { are positive. }\end{array}$ & 1.19 \\
\hline
\end{tabular}

Table A2. Sample demographics $(\mathrm{N}=737)$.

\begin{tabular}{|c|c|c|c|}
\hline Measure & Item & Count & $\%$ \\
\hline \multirow[t]{3}{*}{ Gender } & Male & 302 & $41.0 \%$ \\
\hline & Female & 413 & $56.0 \%$ \\
\hline & No answer & 22 & $3.0 \%$ \\
\hline \multirow[t]{11}{*}{ Age } & 14 and below & 1 & $0.1 \%$ \\
\hline & 15-19 & 15 & $2.0 \%$ \\
\hline & $20-24$ & 472 & $64.0 \%$ \\
\hline & $25-29$ & 113 & $15.3 \%$ \\
\hline & $30-34$ & 38 & $5.2 \%$ \\
\hline & $25-39$ & 22 & $3.0 \%$ \\
\hline & $40-44$ & 24 & $3.3 \%$ \\
\hline & $55-59$ & 7 & $0.9 \%$ \\
\hline & 60-64 & 1 & $0.1 \%$ \\
\hline & 65 and over & 5 & $0.7 \%$ \\
\hline & No answer & 9 & $1.2 \%$ \\
\hline \multirow[t]{5}{*}{ Education } & Unfinished primary school & 3 & $0.4 \%$ \\
\hline & Primary school & 3 & $0.4 \%$ \\
\hline & High school & 325 & $44.1 \%$ \\
\hline & University degree & 390 & $52.9 \%$ \\
\hline & No answer & 16 & $2.2 \%$ \\
\hline
\end{tabular}

Table A3. Analysis of indirect effects of positive comments through eWOM (COMM) on PINT.

\begin{tabular}{ccccc}
\hline $\begin{array}{c}\text { Indirect Effects of COMM on } \\
\text { PINT (Standardized) }\end{array}$ & $\boldsymbol{p}$ Values & S.E. & \multicolumn{2}{c}{ Confidence Intervals } \\
\cline { 3 - 5 } & & & $\mathbf{- 2 . 5 \%}$ & SS Estimate \\
\hline Total & 0.001 & 0.064 & 0.092 & 0.216 \\
Total indirect & 0.114 & 0.023 & -0.009 & 0.036 \\
COMM-TC-PINT & 0.191 & Specific indirect & & 0.341 \\
COMM-TC-IGIC-PINT & 0.123 & 0.011 & -0.007 & 0.015 \\
Direct COMM-PINT & 0.003 & 0.014 & -0.006 & 0.021 \\
\hline
\end{tabular}

\section{References}

1. Berthon, P.R.; Pitt, L.F.; Plangger, K.; Shapiro, D. Marketing meets Web 2.0, social media, and creative consumers: Implications for international marketing strategy. Bus. Horiz. 2012, 55, 261-271. [CrossRef]

2. Stephen, A.T.; Toubia, O. Deriving value from social commerce networks. J. Mark. Res. 2010, 47, 215-228. [CrossRef]

3. Labelinsight. How consumer demand for transparency is shaping the food industry. In The 2016 Label Insight Food Revolution Study; Labelinsight: Chicago, IL, USA, 2016.

4. Zegler, J. Global Food E Drink Trends; Editorial Mintel: Chicago, IL, USA, 2018. 
5. $\quad$ Ringquist, J.; Phillips, T.; Renner, B.; Sides, R.; Stuart, K.; Baum, M.; Flannery, J. Capitalizing on the Shifting Consumer Food Value Equation; Deloitte Development LLC: Hermitage, TN, USA, 2016.

6. Food Marketing Institute. U.S. Grocery Shopper Trends; Food Marketing Institute: Washington, DC, USA, 2017.

7. Lee, J.Y. Trust and Social Commerce. Univ. Pittsburgh Law Rev. 2015, 77, 137-181. [CrossRef]

8. Jansen, B.J.; Zhang, M.; Sobel, K.; Chowdury, A. Twitter power: Tweets as electronic word of mouth. J. Am. Soc. Inf. Sci. Technol. 2009, 60, 2169-2188. [CrossRef]

9. Hennig-Thurau, T.; Gwinner, K.P.; Walsh, G.; Gremler, D.D. Electronic word-of-mouth via consumer-opinion platforms: What motivates consumers to articulate themselves on the Internet? J. Interact. Mark. 2004, 18, 38-52. [CrossRef]

10. Herr, P.M.; Kardes, F.R.; Kim, J. Effects of Word-of-Mouth and on Product-An Attribute Persuasion: Perspective. J. Consum. Res. 1991, 17, 454-462. [CrossRef]

11. López, M.; Sicilia, M. Determinants of E-WOM Influence: The Role of Consumers' Internet Experience. J. Theor. Appl. Electron. Commer. Res. 2014, 9, 28-43. [CrossRef]

12. Hajli, N. A study of the impact of social media on consumers. Int. J. Mark. Res. 2014, 56, 387-404. [CrossRef]

13. Han, B.; Windsor, J. User's willingness to pay on social network sites. J. Comput. Inf. Syst. 2011, 51, 31-40.

14. Grewal, R.; Cline, T.W.; Davies, A. Early-Entrant Advantage, Word-of-Mouth Communication, Brand Similarity, and the Consumer Decision-Making Process. J. Consum. Psychol. 2003, 13, 187-197. [CrossRef]

15. Seifert, C.; Kwon, W.S. SNS eWOM sentiment: Impacts on brand value co-creation and trust. Mark. Intell. Plan. 2019, 38, 89-102. [CrossRef]

16. Baird, C.H.; Parasnis, G. From social media to social customer relationship management. Strategy Leadersh. 2011, 39, 30-37. [CrossRef]

17. $\mathrm{Wu}$, J.J.; Chen, Y.H.; Chung, Y.S. Trust factors influencing virtual community members: A study of transaction communities. J. Bus. Res. 2010, 63, 1025-1032. [CrossRef]

18. Cheung, C.M.K.; Lee, M.K.O.; Thadani, D.R. The impact of positive electronic word-of-mouth on consumer online purchasing decision. In World Summit on Knowledge Society; Springer: Berlin/Heidelberg, Germany, 2009; pp. 501-510.

19. Lu, B.; Fan, W.; Zhou, M. Computers in Human Behavior Social presence, trust, and social commerce purchase intention: An empirical research. Comput. Hum. Behav. 2016, 56, 225-237. [CrossRef]

20. Gefen, D.; Karahanna, E.; Straub, D.W. Trust and TAM in Online Shopping: An Integrated Model. MIS Q. 2003, 27, 51-90. [CrossRef]

21. Hajli, N.; Sims, J.; Zadeh, A.H.; Richard, M.O. A social commerce investigation of the role of trust in a social networking site on purchase intentions. J. Bus. Res. 2017, 71, 133-141. [CrossRef]

22. Darby, M.R.; Karni, E. Free Competition and the Optimal Amount of Fraud. J. Law Econ. 1973, 16, 67-88. [CrossRef]

23. Nelson, P. Information and consumer behavior. J. Polit. Econ. 1970, 78, 311-329. [CrossRef]

24. Dentoni, D.; Tonsor, G.T.; Calantone, R.J.; Peterson, H.C. The Direct and Indirect Effects of 'Locally Grown' on Consumers' Attitudes towards Agri-Food Products. Agric. Resour. Econ. Rev. 2009, 38, 384-396. [CrossRef]

25. Janssen, M.; Hamm, U. The mandatory EU logo for organic food: Consumer perceptions. Br. Food J. 2012, 114, 335-352. [CrossRef]

26. Sogn-Grundvag, G.; Larsen, T.A.; Young, J.A. Product Differentiation with Credence Attributes and Private Labels: The Case of Whitefish in UK Supermarkets. J. Agric. Econ. 2014, 65, 368-382. [CrossRef]

27. Lassoued, R.; Hobbs, J.E.; Micheels, E.T.; Zhang, D. Di Consumer Trust in Chicken Brands: A Structural Equation Model. Can. J. Agric. Econ. 2015, 63, 621-647. [CrossRef]

28. Hu, W.; Chen, K.; Yoshida, K. Japanese Consumers' Perceptions on and Willingness to Pay for Credence Attributes Associated with Canola Oil. J. Agric. Appl. Econ. 2006, 38, 91-103. [CrossRef]

29. Yang, W.; Renwick, A. Consumer Willingness to Pay Price Premiums for Credence Attributes of Livestock Products-A MetaAnalysis. J. Agric. Econ. 2019, 70, 618-639. [CrossRef]

30. Siering, M.; Muntermann, J. Credence Goods and Online Product Reviews: An Exploration of the Product Type Concept in the Social Commerce Era. In Proceedings of the 19th Americas Conference on Information Systems (AMICS 2013), Chicago, IL, USA, 15-17 August 2013; pp. 918-925.

31. European Commission. 2019 SBA Fact Sheet: Serbia; European Commission: Brussels, Belgium, 2020.

32. Government of Serbia. Strategija Poljoprivrede i Ruralnog Razvoja Republike Srbije za Period 2014-2024. Godine; Official Gazette of the Republic of Serbia: Belgrade, Serbia, 2014; Volume 85/14.

33. Chatterjee, S.; Kumar Kar, A. Why do small and medium enterprises use social media marketing and what is the impact: Empirical insights from India. Int. J. Inf. Manag. 2020, 53, 102103. [CrossRef]

34. Gefen, D.; Straub, D.W. Consumer trust in B2C e-Commerce and the importance of social presence: Experiments in e-Products and e-Services. Omega 2004, 32, 407-424. [CrossRef]

35. Stewart, K.J. Trust Transfer on the World Wide Web. Organ. Sci. 2003, 14, 5-17. [CrossRef]

36. Fishbein, M.; Ajzen, L. Belief, Attitude, Intention and Behavior: An Introduction to Theory and Research; Addison-Wesley: Reading, MA, USA, 1975; ISBN 0201020890.

37. Rotter, J.B. A new scale for the measurement of interpersonal trust. J. Personal. 1967, 35, 651-665. [CrossRef]

38. Schurr, P.H.; Ozanne, J.L. Influences on Exchange Processes: Buyers' Preconceptions of a Seller's Trustworthiness and Bargaining Toughness. J. Consum. Res. 1985, 11, 939-953. [CrossRef] 
39. Mayer, R.C.; Davis, J.H.; Schoorman, D.F. An Integrative Model of Organizational Trust. Acad. Manag. Rev. 1995, 20 , 709-734. [CrossRef]

40. McKnight, D.H.; Choudhury, V.; Kacmar, C. Developing and validating trust measures for e-commerce: An integrative typology. Inf. Syst. Res. 2002, 13, 334-359. [CrossRef]

41. McKnight, D.H.; Chervany, N.L. Reflections on an initial trust-building model. In The Handbook of Trust Research; Edward Elgar: Cheltenham, UK, 2006; pp. 29-51.

42. Shi, S.; Chow, W. Trust development and transfer in social commerce: Prior experience as moderator. Ind. Manag. Data Syst. 2015, 115, 1182-1203. [CrossRef]

43. Campbell, D.T. Common fate, similarity, and other indices of the status of aggregates of persons as social entities. Behav. Sci. 1958, 3, 14-25. [CrossRef]

44. Lu, Y.; Zhao, L.; Wang, B. Electronic Commerce Research and Applications From virtual community members to C2C e-commerce buyers: Trust in virtual communities and its effect on consumers' purchase intention. Electron. Commer. Res. Appl. 2010, 9, 346-360. [CrossRef]

45. Hajli, N.; Lin, X.; Featherman, M.; Wang, Y. Social word of mouth: How trust develops in the market. Int. J. Mark. Res. 2014, 56, 673-689. [CrossRef]

46. Kim, S.; Park, H. Effects of various characteristics of social commerce (s-commerce) on consumers' trust and trust performance. Int. J. Inf. Manag. 2013, 33, 318-332. [CrossRef]

47. Pavlou, P.A.; Gefen, D. Building Effective Online Marketplaces with Institution-Based Trust. Inf. Syst. Res. 2004, 15, 37-59. [CrossRef]

48. Teo, T.S.H.; Liu, J. Consumer trust in e-commerce in the United States, Singapore and China. Omega 2007, 35, 22-38. [CrossRef]

49. Ajzen, I. The theory of planned behavior. Organ. Behav. Hum. Decis. Process. 1991, 50, 179-211. [CrossRef]

50. Kozinets, R.V.; De Valck, K.; Wojnicki, A.C.; Wilner, S.J.S. Networked narratives: Understanding word-of-mouth marketing in online communities. J. Mark. 2010, 74, 71-89. [CrossRef]

51. Galeotti, A.; Goyal, S. Influencing the influencers: A theory of strategic diffusion. RAND J. Econ. 2009, 40, 509-532. [CrossRef]

52. Breazeale, M. Word of mouse: An assessment of electronic word-of-mouth research. Int. J. Mark. Res. 2009, 51, 297-318. [CrossRef]

53. Parsons, A. Using social media to reach consumers: A content analysis of official Facebook pages. Acad. Mark. Stud. J. 2013, 17, 27.

54. Liu, L.; Lee, M.K.O.; Liu, R.; Chen, J. Trust transfer in social media brand communities: The role of consumer engagement. Int. J. Inf. Manag. 2018, 41,1-13. [CrossRef]

55. Di Virgilio, F.; Antonelli, G. Consumer behavior, trust, and electronic word-of-mouth communication: Developing an online purchase intention model. Soc. Media Knowl. Manag. Appl. Mod. Organ. 2017, 1, 58-80. [CrossRef]

56. Gulati, R.; Sytch, M. Does Familiarity Breed Trust? Revisiting the Antecedents of Trust. Manag. Decis. Econ. 2008, 29, 165-190. [CrossRef]

57. Cheng, X.; Fu, S.; de Vreede, G.J. Understanding trust influencing factors in social media communication: A qualitative study. Int J. Inf. Manag. 2017, 37, 25-35. [CrossRef]

58. Golbeck, J. Trust and Nuanced Profile Similarity in Online Social Networks. ACM Trans. Web 2009, 3, 1-33. [CrossRef]

59. Gefen, D.; Karahanna, E.; Straub, D.W. Inexperience and experience with online stores: The importance of TAM and trust. IEEE Trans. Eng. Manag. 2003, 50, 307-321. [CrossRef]

60. Jin, L.; Robey, D. Explaining Cybermediation: An Organizational Analysis of Electronic Retailing. Int. J. Electron. Commer. 1999, 3, 47-66. [CrossRef]

61. Klein, B.; Leffler, K.B. The Role of Market Forces in Assuring Contractual Performance. J. Polit. Econ. 1981, 89, 615-641. [CrossRef]

62. Pavlou, P.A.; Dimoka, A. The Nature and Role of Feedback Text Comments in Online Marketplaces: Implications for Trust Building, Price Premiums, and Seller Differentiation. Inf. Syst. Res. 2006, 17, 392-414. [CrossRef]

63. Tzanetakis, M.; Kamphausen, G.; Werse, B.; von Laufenberg, R. The transparency paradox. Building trust, resolving disputes and optimising logistics on conventional and online drugs markets. Int. J. Drug Policy 2016, 35, 58-68. [CrossRef] [PubMed]

64. Bailey, A.A. Thiscompanysucks.com: The use of the Internet in negative consumer-to-consumer articulations. J. Mark. Commun. 2004, 182, 169-182. [CrossRef]

65. Xia, L.; Bechwati, N.N. Word of Mouse. J. Interact. Advert. 2008, 9, 3-13. [CrossRef]

66. Park, D.; Kim, S. The effects of consumer knowledge on message processing of electronic word-of-mouth via online consumer reviews. Electron. Commer. Res. Appl. 2008, 7, 399-410. [CrossRef]

67. Pavlou, P.A.; Fygenson, M. Understanding and Predicting Electronic Commerce Adoption: An Extension of the Theory of Planned Behavior. MIS Q. 2006, 30, 115-143. [CrossRef]

68. Gefen, D. E-commerce: The role of familiarity and trust. Omega 2000, 28, 725-737. [CrossRef]

69. Crosby, L.; Evans, K.; Cowles, D. Relationship Quality in Services Selling: An Interpersonal Influence Perspective. J. Mark. 1990, 54, 68-81. [CrossRef]

70. Ridings, C.M.; Gefen, D.; Arinze, B. Some antecedents and effects of trust in virtual communities. J. Strategy Inf. Syst. 2002, 11, 271-295. [CrossRef]

71. Bhattacherjee, A. Individual trust in online firms: Scale development and initial test. J. Manag. Inf. Syst. 2002, 19, $211-241$. [CrossRef] 
72. Rahman, Z.; Moghavvemmi, S.; Suberamanaian, K.; Zanuddin, H.; Bin Md Nasir, H.N. Mediating impact of fan-page engagement on social media connectedness and followers purchase intention. Online Inf. Rev. 2018, 42, 1082-1105. [CrossRef]

73. Heiervang, E.; Goodman, R. Advantages and limitations of web-based surveys: Evidence from a child mental health survey. Soc. Psychiatry Psychiatr. Epidemiol. 2011, 46, 69-76. [CrossRef] [PubMed]

74. Bista, K. Examining Factors Impacting Online Survey Response Rates in Educational Research: Perceptions of Graduate Students. Online Submiss. 2017, 13, 63-74.

75. Rolstad, S.; Adler, J.; Rydén, A. Response burden and questionnaire length: Is shorter better? A review and meta-analysis. Value Health 2011, 14, 1101-1108. [CrossRef]

76. Hair, J.F.; Black, W.C.; Babin, B.J.; Anderson, R.E. Multivariate Data Analysis: A Global Perspective; Pearson Education: London, UK, 2010; ISBN 9780135153093.

77. Hair, J.F., Jr.; Matthews, L.M.; Matthews, R.L.; Sarstedt, M. PLS-SEM or CB-SEM: Updated guidelines on which method to use. Int. J. Multivar. Data Anal. 2017, 1, 107-123. [CrossRef]

78. Cerny, B.A.; Kaiser, H.F. A Study of a Measure of Sampling Adequacy for Factor-Analytic Correlation Matrices. Multivar. Bahav. Res. 1977, 12, 43-47. [CrossRef] [PubMed]

79. Kaiser, H.F. An Index of Factorial Simplicity. Pscychometrica 1974, 39, 31-36. [CrossRef]

80. Hutcheson, G.D.; Sofroniou, N. The Multivariate Social Scientist: Introductory Statistics Using Generalized Linear Models; SAGE Publications Ltd.: Thousand Oaks, CA, USA, 1999; ISBN 0761952012.

81. Podsakoff, P.M.; Mackenzie, S.B.; Lee, J.; Podsakoff, N.P. Common Method Biases in Behavioral Research: A Critical Review of the Literature and Recommended Remedies. J. Appl. Psychol. 2003, 88, 879-903. [CrossRef] [PubMed]

82. Field, A.; Miles, J.; Field, Z. Discovering Statistics Using R; SAGE Publications: Thousand Oaks, CA, USA, $2012 ;$ ISBN 1446200469.

83. Kline, P. Handbook of Psychological Testing, 2nd ed.; Routledge: Abingdon, UK, 2000; ISBN 9781315812274.

84. Fornell, C.; Larcker, D.F. Structural Equation Models with Unobservable Variables and Measurement Error. J. Mark. Res. 1981, 18, 39-50. [CrossRef]

85. Henseler, J.; Ringle, C.M.; Sarstedt, M. A new criterion for assessing discriminant validity in variance-based structural equation modeling. J. Acad. Mark. Sci. 2015, 43, 115-135. [CrossRef]

86. Voorhees, C.M.; Brady, M.K.; Calantone, R.; Ramirez, E.; Brady, M.K. Discriminant validity testing in marketing: An analysis, causes for concern, and proposed remedies. J. Acad. Mark. Sci. 2016, 44, 119-134. [CrossRef]

87. Schermelleh-Engel, K.; Moosbrugger, H.; Müller, H. Evaluating the fit of structural equation models: Tests of significance and descriptive goodness-of-fit measures. Methods Psychol. Res. Online 2003, 8, 23-74.

88. Baron, R.M.; Kenny, D.A. The moderator-mediator variable distinction in social psychological research: Conceptual, strategic, and statistical considerations. J. Personal. Soc. Psychol. 1986, 51, 1173-1182. [CrossRef]

89. Fritz, M.S.; MacKinnon, D.P. Required sample size to detect the mediated effect. Psychol. Sci. 2007, 18, 233-239. [CrossRef] [PubMed]

90. Woody, E. An SEM Perspective on Evaluating Mediation: What Every Clinical Researcher Needs to Know. J. Exp. Psychopathol. 2011, 2, 210-251. [CrossRef]

91. MacKinnon, D.P.; Lockwood, C.M.; Williams, J. Confidence Limits for the Indirect Effect: Distribution of the Product and Resampling Methods. Multivar. Behav. Res. 2004, 39, 99-128. [CrossRef]

92. Biesanz, J.C.; Falk, C.F.; Savalei, V. Assessing mediational models: Testing and interval estimation for indirect effects. Multivar. Behav. Res. 2010, 45, 661-701. [CrossRef]

93. Muthén, B.O.; Muthén, L.K.; Asparouhov, T. Regression and Mediation Analysis Using Mplus; Muthén \& Muthén: Los Angeles, CA, USA, 2017; ISBN 0982998317.

94. Dellarocas, C. The Digitization of Word of Mouth: Promise and Challenges of Online Feedback Mechanisms. Manag. Sci. Publ. 2003, 49, 1407-1424. [CrossRef]

95. Prahalad, C.K.; Ramaswamy, V. Co-creating unique value with customers. Strategy Leadersh. 2004, 32, 4-9. [CrossRef]

96. Stevens, J.L.; Spaid, B.I.; Breazeale, M.; Esmark Jones, C.L. Timeliness, transparency, and trust: A framework for managing online customer complaints. Bus. Horiz. 2018, 61, 375-384. [CrossRef]

97. See-To, E.W.K.; Ho, K.K.W. Value co-creation and purchase intention in social network sites: The role of electronic Word-of-Mouth and trust-A theoretical analysis. Comput. Hum. Behav. 2014, 31, 182-189. [CrossRef]

98. Galvagno, M.; Dalli, D. Theory of value co-creation: A systematic literature review. Manag. Serv. Qual. 2014, 24, 643-683. [CrossRef]

99. Tajfel, H.; Turner, J.C. The Social Identity Theory of Intergroup Behavior. In Key Readings in Social Psychology: Political Psychology; Psychology Press: New York, NY, USA, 2004; pp. 276-293. ISBN 9780203505984.

100. Habibi, M.R.; Laroche, M.; Richard, M.O. The roles of brand community and community engagement in building brand trust on social media. Comput. Hum. Behav. 2014, 37, 152-161. [CrossRef] 